\title{
TATALAKSANA TERKINI INFEKSI KAKI DIABETES
}

\section{Gede Surya Dinata ${ }^{1}$, Anak Agung Gede Wira Pratama Yasa ${ }^{2}$}

\author{
${ }^{1}$ Prodi Kedokteran, Universitas Pendidikan Ganesha \\ ${ }^{2}$ Prodi Kedokteran, Universitas Pendidikan Ganesha
}

e-mail: surya.dinata@undiksha.ac.id, anak.agung.wira@undiksha.ac.id

\begin{abstract}
Abstrak
Laporan dari International Diabetes Federation Tahun 2019 menyebutkan bahwa tingkat kejadian Diabetes Melitus (DM) meningkat setiap tahunnya dan diperkirakan sekitar 629 Juta orang di seluruh dunia menderita DM pada tahun 2045. Hal ini tentunya berdampak pada peningkatan dari komplikasi yang ditimbulkan oleh DM salah satunya adalah Diabetic Foot Infection (DFI) atau Infeksi Kaki Diabetes (IKD). IKD merupakan komplikasi lanjutan dari kaki diabetik yang ditandai oleh adanya proses invasi mikroorganisme yang berkembang di jaringan dalam seperti kulit, otot, tendon, sendi, tulang pada ekstremitas bawah, tepatnya di bawah malleoli. IKD dapat menimbulkan morbiditas dan mortalitas yang signifikan, termasuk kecacatan, mobilitas berkurang, penurunan kualitas hidup pada aspek fisik dan mental, serta ancaman kehilangan anggota tubuh oleh karena amputasi. Selain itu, penyakit ini juga dikaitkan dengan komplikasi DM lainnya seperti komplikasi neuropati perifer, Peripheral Arterial Disease (PAD), dan infeksi pada pasien DM. Dalam melakukan tatalaksana terhadap pasien DM dengan ataupun berisiko IKD, diperlukan perawatan lebih lanjut yang harus didasari dengan tingkat keparahan infeksi. Sebagian besar kasus IKD memiliki kecenderungan amputasi sehingga penting untuk dilakukan penatalaksanaan dan pencegahan secara komprehensif dengan melibatkan manajemen multidisiplin dengan ahli bedah (umum, vaskular, ortopedi), penyakit dalam, dan perawat luka, sehingga dapat mengurangi waktu penyembuhan luka, tingkat, dan keparahan amputasi.
\end{abstract}

Kata kunci: diabetes melitus, infeksi kaki diabetes, tatalaksana, amputasi

\begin{abstract}
The report from the International Diabetes Federation in 2019 states that the incidence of Diabetes Melitus (DM) is increasing every year and it is estimated that around 629 million people worldwide suffer from DM in 2045. This of course has an impact on the increase in complications caused by DM, one of which is Diabetic. Foot infection (DFI). DFI is a further complication of diabetic foot which is characterized by the invasion of microorganisms that develop in deep tissues such as skin, muscles, tendons, joints, bones in the lower extremities, precisely under the malleoli. DFI can cause significant morbidity and mortality, including disability, reduced mobility, decreased quality of life in physical and mental aspects, and the threat of limb loss due to amputation. In addition, this disease is also associated with other DM complications such as complications of peripheral neuropathy, Peripheral Arterial Disease (PAD), and infections in DM patients. In treating DM patients with or at risk of DFI, further treatment is needed that must be based on the severity of the infection. Most cases of DFI have a tendency to amputate so it is important to carry out comprehensive management and prevention involving multidisciplinary management with surgeons (general, vascular, orthopedic), internal medicine, and wound nurses, so as to reduce wound healing time, rate, and severity of amputations.
\end{abstract}

Keywords: diabetes melitus, diabetic foot infection, treatment, amputation 


\section{PENDAHULUAN}

Penyakit kencing manis atau diabetes melitus (DM) di era masyarakat modern masih menjadi masalah kesehatan utama. Hampir setengah miliar orang di seluruh dunia mengalami kondisi ini pada tahun 2014 (Jneid et al., 2017). Diperkirakan angka insiden akan tetap meningkat, dengan jumlah sekitar 300 juta orang di dunia akan mengidap penyakit ini pada tahun 2025 (Schwartz et al., 2013). Data WHO pada tahun 2016 menunjukkan penyakit DM masuk dalam 10 besar penyebab kematian dunia dengan angka kematian sebesar 1,6 juta jiwa pada tahun 2016 (WHO, 2016)

Infeksi Kaki Diabetes (IKD) atau diabetic foot infections (DFI), adalah salah satu komplikasi utama diabetes melitus yang paling sering dijumpai. Penderita diabetes memiliki risiko 10x lipat lebih tinggi untuk terjadinya infeksi kulit, jaringan lunak dan tulang (Lavery et al,2006). Hal ini terkait dengan kerentanan terhadap luka oleh karena gangguan sensibilitas dan penurunan perfusi pada tungkai. IKD dapat menimbulkan morbiditas dan mortalitas yang signifikan, termasuk kecacatan, mobilitas berkurang, penurunan kualitas hidup pada aspek fisik dan mental, serta ancaman kehilangan anggota tubuh oleh karena amputasi (Schwartz, 2013) Tingkat keparahan infeksi berkisar dari infeksi kulit ringan hingga infeksi yang menyebabkan nekrosis luas dan dalam dan/atau osteomielitis. IKD juga merupakan penyebab tingginya angka pasien yang masuk rumah sakit terkait dengan DM, dan secara signifikan mempengaruhi prognosis (IWGDF, 2019). Biaya ekonomi untuk mengobati DM, sebagian besar disebabkan oleh prosedur medis untuk merawat IKD, yaitu pemeriksaan kultur bakteri dari sampel jaringan dasar luka, pengobatan dengan antibiotika, perawatan luka serta pembedahan untuk debridement atau amputasi. Amputasi tungkai memberi pengaruh negatif terhadap prognosis penderita, sehingga sedapat mungkin harus dihindari, kecuali ada indikasi yang jelas (Pitocco et al., 2019). Karena itu, semua upaya harus diarahkan untuk mencegah pembentukan ulkus atau luka dan terjadinya infeksi oleh bakteri pathogen. Tingkat keparahan infeksi, yang bisa dinilai dari keadaan klinis luka menentukan tidak saja pengobatan, namun juga prognosis pasien.

\section{METODE}

Penulisan artikel ini bedasarkan metode literature review dari artikel penelitian terkait dengan diagnosis dan tatalaksana Infeksi Kaki Diabetes (IKD) yang sudah terpublikasi. Artikel penelitian didapatkan bedasarkan hasil penelusuranpada platform PubMed, Science Direct, Cermin Dunia Kedokteran (CDK), dan Google Scholar dengan memasukan kata kunci yang telah ditentukan sesuai dengan judul artikel. Artikel yang digunakan merupakan artikel yang dipublikasi pada 10 tahun terakhir yaitu mulai dari tahun 2011 hingga tahun 2021.

\section{HASIL DAN PEMBAHASAN}

Infeksi Kaki Diabetes (IKD) adalah suatu kondisi dimana terdapat invasi oleh mikro-organisme yang kemudian berkembang di jaringan tubuh pasien diabetes, dengan lokasi disebelah distal dari malleoli, dan menginduksi terjadinya respon inflamasi. Beberapa factor predisposisi terjadinya IKD pada pasien diabetes adalah adanya neuropati, vaskulopati, immunopati, dan biomekanika kaki (Pitocco et al., 2019).

Kehilangan sensasi protektif akibat neuropati perifer pada IKD merupakan faktor pemicu dan pendahulu terbentuknya ulkus pada kaki. Ulkus atau kerusakan pad lapisan epitel kulit merupakan pintu masuk terjadinya infeksi. Kerusakan saraf sebagai pemicu ulkus, dapat melibatkan saraf sensoris, motoric maupun otonom. Ketidakseimbangan motoric oleh karena motor neuropati, menyebabkan terjadinya atrofi otot, dislokasi bantalan lemak, dan akhirnya terjadi deformitas pada kaki, seperti; foot drop, clawed/hammer toes, equinus varus/valgus. Deformitas pada kaki menyebabkan terbentuknya daerah pada kaki yang mengalami tekanan abnormal, sehingga rentan terhadap trauma. Hilangnya sensasi pada kulit kaki menngakibatkan ketidakmampuan mencegah terjadinya trauma, atau adanya trauma yang tak disadari yang memperburuk keadaan. Area kaki yang 
menjadi tumpuan saat berjalan dan menahan beban mengalami penekanan dan gesekan berulang sehingga. Ditambah dengan hilangnya fungsi kelenjar keringat dan lemak menjadikan kulit kaki menjadi kering dan mengalami hyperkeratosis, sehingga lebih mudah pecah dan menjadi sumber masuknya bakteri.

Gangguan yang terjadi pada pembuluh arteri hinga kapiler (angiopati) menyebabkan peningkatan risiko komplikasi pada pasien diabetes. Pengapuran/ atherosclerosis dan penyempitan/stenosis pada pembuluh darah arteri pada tungkai merupakan pangkal terjadinya penyakit pembuluh darah perifer (peripheral arterial disease/PAD). Aliran darah yang terhambat, dibarengi dengan sirkulasi kolateral yang tidak cukup, menyebabkan iskemia jaringan, penebalan membrane basalis kapiler, gangguan penyerapan nutrisi, hipoksia dan akhirnya kematian sel dan jaringan. Penelitian oleh Peters et al., tahun 2016 menyimpulkan factor risiko untuk IKD adalah PAD, Riwayat amputasi sebelumnya, dan neuropati.

Faktor pasien yang tidak memperhatikan kebersihan kaki dan penggunaan alas kaki yang tidak sesuai, merupakan penyebab utama terjadinya IKD yang seharusnya dapat dicegah. Hilangnya sensasi akibat neuropati, gangguan penglihatan yang cukup sering terjadi pada pasien diabetes, dapat menyebabkan luka/abrasi, kemerahan menjadi tidak terdeteksi. Sekitar $60 \%$ dari infeksi yang terjadi pada pasien DM, berawal dari interdigital/web space, 30\% mulai dari daerah kuku, sedangkan 10\% terjadi sekunder akibat trauma penetrasi. Secara klinis, infeksi kaki diabetic dapat berupa selulitis akut yang ringan hingga terjadinya fasciitis necrotican yang mengancam nyawa.

Salah satu sistem klasifikasi kaki diabetic yang paling umum digunakan adalah sistem Wagner-Meggit. Sistem klasifikasi enam tingkat ini mempertimbangkan kedalaman ulkus, adanya gangren, dan luasnya nekrosis jaringan. Meskipun penilaian WagnerMeggit adalah salah satu sistem klasifikasi yang paling banyak digunakan, ini tidak memperhitungkan parameter klinis yang penting, seperti iskemia, infeksi, atau faktor penyerta lainnya (Tabel 1) (Pitocco, et al, 2019). Selain itu terdapat pula sistem klasifikasi lainnya seperti sistem klasifikasi IKD berdasarkan Infectious Diseases Society of America (IDSA) dan International Working Group on the Diabetic Foot (IWGDF) serta sistem dari University of Texas.

\begin{tabular}{|c|c|}
\hline Grade & Definisi \\
\hline 0 & $\begin{array}{l}\text { Pra ulseratif, tanpa lesi terbuka } \\
\text { atau selulitis }\end{array}$ \\
\hline 1 & Ulkus superfisial \\
\hline 2 & $\begin{array}{l}\text { Ulkus dalam sampai ke tendon } \\
\text { dan jaringan sendi }\end{array}$ \\
\hline 3 & $\begin{array}{l}\text { Ulkus dalam dengan abses, } \\
\text { osteomielitis, dan sepsis sendi }\end{array}$ \\
\hline 4 & $\begin{array}{l}\text { Gangren lokal pada kaki depan } \\
\text { atau tumit }\end{array}$ \\
\hline 5 & $\begin{array}{l}\text { Gangren seluruh kaki / gangren } \\
\text { global }\end{array}$ \\
\hline
\end{tabular}

Diagnosis infeksi didasarkan pada adanya purulensi, atau setidaknya dua gejala klasik atau tanda inflamasi (misalnya eritema, edema, hangat, nyeri tekan, nyeri, atau indurasi). Tanda-tanda sekunder dalam kasus kaki neuropatik termasuk jaringan granulasi yang rapuh atau berubah warna, bau busuk, cairan tidak bernanah, dan penyembuhan luka yang tertunda. Penekanan yang tepat harus ditempatkan pada evaluasi faktor risiko IKD, termasuk probe-to-bone (PTB) positif, adanya ulserasi selama lebih dari 30 hari, riwayat ulkus kaki berulang, etiologi traumatis, adanya penyakit arteri perifer pada tungkai yang terkena, riwayat amputasi ekstremitas bawah, kurangnya sensasi protektif, insufisiensi ginjal atau riwayat berjalan tanpa alas kaki. Diperlukan pula penjelasan yang memadai untuk memetakan kemajuan selama pengobatan, yakni tentang karakteristik ulkus, seperti ukuran, kedalaman, dasar, tepi, penampakan, dan lokasi. Penilaian menyeluruh terhadap keberadaan jaringan granulasi atau pengelupasan harus dilakukan di dasar ulkus untuk menentukan penatalaksanaan selanjutnya (Pitocco, et al, 2019). 
Pasien dengan IKD juga harus dievaluasi dengan benar untuk insufisiensi arteri dan kondisi neuropatik pada jadwal terstruktur berdasarkan faktor risiko yang ditentukan. Adanya demam, takikardia, atau takipnea dapat mengindikasikan luka yang terinfeksi. Status vaskular harus didokumentasikan dengan meraba semua denyut perifer, atau dengan menggunakan Doppler genggam untuk denyut pedal yang tidak teraba atau samar. Pemeriksaan neurologis juga diperlukan untuk secara klinis menangani ulkus kaki diabetik dan penyembuhannya (Pitocco, et al, 2019). tingkat amputasi, dan keparahan amputasi (Everett and Mathioudakis, 2018). Rekontruksi yang baik dengan atau tanpa amputasi harus menjadi bagian dari rencana perawatan dalam meminimalisir risiko ulserasi berulang. Alur manajemen infeksi yang dapat dilihat pada Gambar 1.

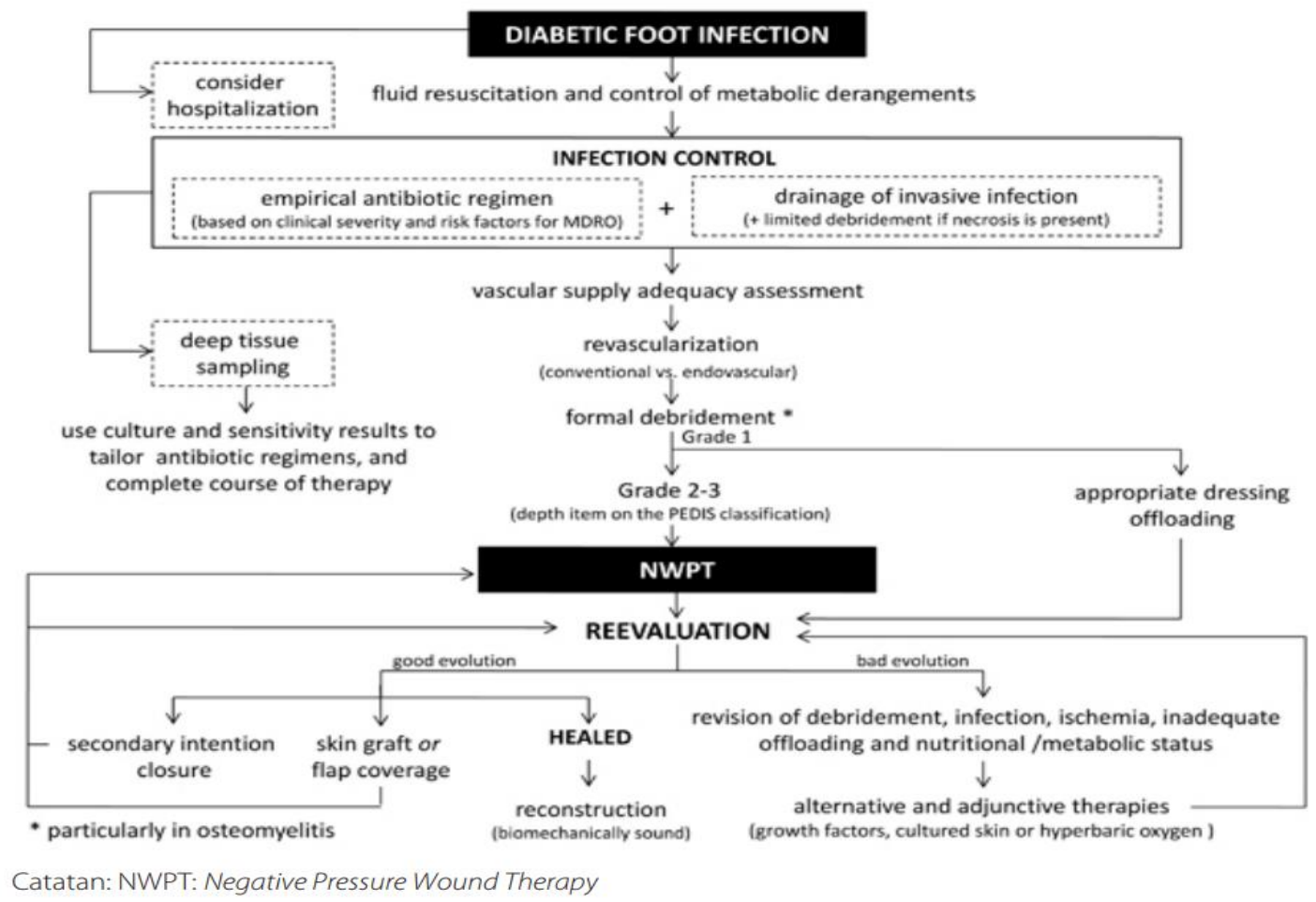

Gambar 1 Algoritma manajemen infeksi kaki diabetik dengan pendekatan multidisiplin (Hutagalung et al, 2019)

Perawatan lebih lanjut harus didasari dengan tingkat keparahan infeksi. Sebagian besar kasus IKD memiliki kecenderungan dalam indikasi amputasi sehingga penting untuk dilakukan pencegahan secara komprehensif. Manajemen multidisiplin yang melibatkan ahli bedah (umum, vaskular, ortopedi), penyakit dalam, dan perawat luka, saat ini menjadi standar baru perawatan dan telah menunjukkan hasil positif dalam mengurangi waktu penyembuhan luka,

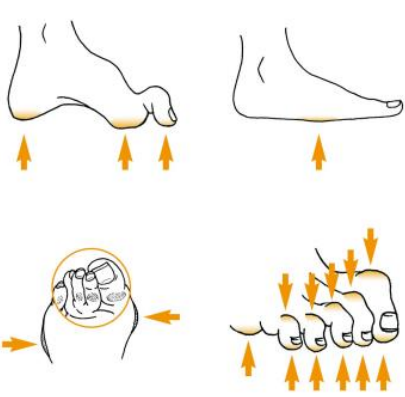

Gambar 2 Area kaki yang memiliki risiko tinggi terbentuk ulserasi (Schaper et al., 2020) 
Infeksi yang terjadi pada pasien IKD menjadi prediktor yang dapat memperburuk keadaan pasien sehingga penggunaan antibiotik sangat penting untuk meningkatkan perbaikan (Everett and Mathioudakis, 2018). Sebelum diberikan terapi antibiotik, dianjurkan untuk melakukan biopsi kultur jaringan dalam terlebih dahulu. Menurut beberapa studi tentang penggunaan antibiotik, sebagian besar menggunakan agen yang menargetkan bakteri gram positif terutama pada infeksi ringan hingga sedang (Everett and Mathioudakis, 2018; Pitocco et al., 2019). Ini dikarenakan adanya infeksi Methicilin-Resistant Staphylococcus Aureus (MRSA) selama masa perawatan memperpanjang waktu penyembuhan luka, meningkatkan kebutuhan pembedahan, hingga berisiko kegagalan pengobatan (Pitocco et al., 2019). Antibiotik spektrum luas mencakup spesies basil Gram-negatif dan enterococcus diperlukan pada pasien yang pernah sebelumnya dirawat atau parah. The Infectious Diseases Society of America (IDSA) merekomendasikan penggunaan antibiotik selama 1-2 minggu pada infeksi ringan, dan infeksi sedang hingga berat selama 2-3 minggu, dan dapat di hentikan setelah tanda dan gejala infeksi teratasi (Everett and Mathioudakis, 2018). Pengobatan konservatif seperti antibiotik oral dan parenteral jangka panjang terbukti efektif pada pasien dengan ulkus kaki atau dugaan osteomielitis (Pitocco et al., 2019).

Tujuan dari pembedahan pada pasien IKD adalah meminimalisir nekrosis jaringan dan mengangkat jaringan yang terinfeksi. Beberapa kondisi tertentu seperti gangren gas, nekrosis faciitis, sindrom kompartemen, sepsis sistemik merupakan salah satu indikasi pembedahan darurat (Lipsky et al., 2020). Dalam tatalaksana pasien IKD, metode yang sering dilakukan adalah debridemen tajam yang termasuk debridemen klinis dan eksisi pembedahan, yang menggunakan pisau bedah, gunting, dan kuretase, dengan kelemahan sulit untuk membersihkan jaringan secara agresif dan steril (Ahmad, 2016). Debridemen luka digunakan untuk melakukan pengangkatan semua jaringan nekrotik dan menghilangkan hal yang tidak sesuai dengan penyembuhan, serta kalus di sekitarnya. Proses ini membantu dalam pembentukan jaringan granulasi dan reepitelisasi yang akan mengurangi tekanan plantar di daerah kalus. Debridemen juga memainkan peran penting dalam pengendalian infeksi, karena jaringan yang mengalami devitalisasi menyediakan nidus untuk proliferasi bakteri (Everett and Mathioudakis, 2018). Beberapa ahli bedah menganjurkan tatalaksana Transtibial Amputation (TTA) sebagai pilihan bedah utama untuk ulserasi kaki yang tak bisa disembuhkan. Kombinasi bedah dengan antibiotik manik-manik (beads) kalsium sulfat dapat diserap tubuh ke dalam luka bedah yang meningkatkan efek Transmetatarsal Amputation (TMA) pada ulserasi diabetik bagian forefoot, sehingga berdampak signifikan pada pengelolaan ulkus bagian forefoot yang akan mencegah rawat inap tambahan di Rumah Sakit sekaligus meningkatkan perawatan serta kualitas hidup pasien (Pitocco et al., 2019). Terapi antibiotik maupun pembedahan saja tidaklah cukup untuk mengatasi gangguan suplai vaskular, kontrol glikemik, atau trauma luka persisten, sehingga diperlukan perawatan terhadap luka pada pasien IKD. Sebagian besar Diabetic Foot Ulcers DFU) perlu dibersihkan dan didebridasi dengan hatihati untuk menghilangkan jaringan yang rusak yang dapat menghambat penyembuhan luka dan mendorong infeksi (Lipsky et al., 2020). Secara umum, DFU dengan eksudat berat membutuhkan balutan yang menyerap kelembapan, sedangkan luka kering membutuhkan perawatan topikal yang menambah kelembapan. Perban harus diganti secara optimal setidaknya setiap hari, baik untuk mengaplikasikan penutup luka yang bersih dan untuk memungkinkan pemeriksaan luka yang cermat terhadap infeksi.

Adapun jenis perawatan luka seperti Negative Pressure Wound Therapy (NPWT) yang merupakan perawatan luka dengan balutan khusus seperti adhesive drape dan busa sel terbuka, yang dipotong untuk mengisi cacat pada luka dan mampu mentransmisikan tekanan konstan atau intermiten menggunakan mekanisme kontrol umpan balik (Ahmad, 2016). Terapi 
ini sering digunakan karena dapat mengumpulkan volume eksudat luka yang tinggi, mengurangi frekuensi pergantian balutan, menjaga kebersihan luka secara anatomis, dan dapat mengurangi bau pada luka, serta dapat membantu meningkatkan perfusi, mengekstrasi bahan infeksius, dan membantu mendekatkan antar luka (Everett and Mathioudakis, 2018). Hasil dari strategi manajemen luka ini menghasilkan perawatan di rumah sakit yang lebih singkat dan persentase penyelamatan anggota tubuh yang lebih tinggi sehingga dapat menurunkan biaya medis secara keseluruhan (Ahmad, 2016).

\section{KESIMPULAN}

Infeksi Kaki Diabetes merupakan penyakit yang dapat menyebabkan amputasi ekstremitas bawah hingga kematian bagi penderitanya. Insiden kasus penyakit ini meningkat seiring dari peningkatan jumlah penderita diabetes melitus. Diperlukan serangkaian pemeriksaan dan evaluasi mulai dari lokal hingga sistemik secara multidisiplioner sebagai bagian dari tatalaksana yang holistik dan komprehensif, dengan sejumlah modalitas terapi mulai dari perawatan konservatif, antibiotik, perawatan luka, pembedahan, maupun kombinasinya tergantung kondisi pasien sehingga dapat memberikan hasil yang terbaik.

\section{DAFTAR PUSTAKA}

Ahmad, J. (2016). 'The diabetic foot', Diabetes and Metabolic Syndrome: Clinical Research and Reviews. Diabetes India, 10(1), pp. 48-60. doi: 10.1016/j.dsx.2015.04.002.

Datta, A., Singh M. (2011). Antimicrobial Property of Piper betel Leaf against Clinical Isolates of Bacteria. Int $\mathrm{J}$ Pharm Sci Res 2.

Everett, E. and Mathioudakis, N. (2018). 'Update on management of diabetic foot ulcers', Annals of the New York Academy of Sciences, 1411(1), pp. 153-165. doi: 10.1111/nyas. 13569 .

Hutagalung, M. B. Z. et al. (2019). 'Diabetic Foot Infection (Infeksi Kaki Diabetes): Diagnosis dan Tatalaksana', Continuing Medical Education, 46(6), pp. 414-418.
IWGDF. (2019). Guidelines on the prevention and management of diabetic foot disease IWGDF Guidelines. Retrieved from www.iwgdfguidelines.org

J. Jneid, J. P. Lavigne, B. La Scola, N. Cassir. (2017) The diabetic foot microbiota: A review. Human Microbiome Journal. 5-6, pp. 1-6.

Lipsky, B. A. et al. (2020) 'Guidelines on the diagnosis and treatment of foot infection in persons with diabetes (IWGDF 2019 update)', Diabetes/Metabolism Research and Reviews, 36(S1), pp. 1-24. doi: 10.1002/dmrr.3280.

Pitocco, D, Spanu, T, Sanguinetti, M. (2019). Diabetic foot infections: a comprehensive overview. European review for medical and pharmacological sciences 23, 2637. doi:10.26355/eurrev_201904_1747 1

S. A. V. van Asten et al. (2016). The microbiome of diabetic foot osteomyelitis. European Journal of Clinical Microbiology and Infectious Diseases. 35, 293-298

Schaper, N. C. et al. (2020) 'Practical Guidelines on the prevention and management of diabetic foot disease (IWGDF 2019 update)', Diabetes/Metabolism Research and Reviews, 36(S1), pp. 1-10. doi: 10.1002/dmrr.3266.

Schwartz JA, Lantis II JC, Gendics C, Fuller AM, Payne W, Ochs D. (2013) A prospective, noncomparative, multicenter study to investigate the effect of cadexomer iodine on bioburden load and other wound characteristics in diabetic foot ulcers. Int Wound J; 10:193- 